\title{
Televisão brasileira e ditadura militar: tudo a ver com o que está aí até hoje ${ }^{1}$
}

\section{Brazilian television and military dictatorship: everything to do with what is happening today}

\author{
Eugênio Bucci²
}

\footnotetext{
1 Texto originalmente apresentado como palestra durante o seminário "Ditadura e cultura: o golpe de 64 e a cultura brasileira" no anfiteatro do curso de História na Faculdade de Filosofia, Letras e Ciências Humanas da Universidade de São Paulo (FFLCH-USP), realizado entre os dias 17 e 19 de setembro de 2014, sob organização de Augusto Massi e Priscila Figueiredo.
} 


\section{Resumo}

\section{Palavras-chave}

Dados os parâmetros gerais da transformação do espaço público ao longo do século $X X$, em razão dos meios de comunicação de massa, o presente trabalho analisa a conversão do espaço público no Brasil tal como foi posto pela instância da palavra impressa - em telespaço público, regido pela instância da imagem ao vivo, segundo uma nova conformação e sujeito a outras leis comunicacionais. A ditadura militar no Brasil, a partir da iniciativa do Estado, realizou a "modernização" tecnológica do sistema de mediações e midiatizações no espaço público nacional ao mesmo tempo que "desmodernizou" a política. Essa estrutura se mantém no telespaço público brasileiro, já que a organização da cultura promovida então pouco se alterou.

Televisão, ditadura militar, instância da palavra impressa, telespaço público, instância da imagem ao vivo.

\section{Abstract}

Considering the general guidelines of the public space transformation during the 20th century associated with mass media communication, the present work analyzes the conversion of the Brazilian public space established by print media instance - into a public telespace, conducted by the instance of live images, based in new rules and subject to different communication laws. The military dictatorship in Brazil has performed, through state initiatives, a technologic "modernization" of the country's system of mediation and mediatization in the public national space and, simultaneously, has "demodernized" politics. Such structure remains in the Brazilian public telespace, since the country's culture organization shows little changes.

\section{Keywords}

Television, military dictatorship, print media instance, public telespace, live image instance. 
São conhecidos os parâmetros gerais da transformação do espaço público ao longo do século XX por causa dos meios de comunicação de massa. Prefiro dizer que o que houve foi uma conversão do espaço público - tal como foi posto pela instância da palavra impressa - em telespaço público. Pode-se dizer que o telespaço público nada mais é que o espaço público regido pela instância da imagem ao vivo, segundo uma nova conformação e sujeito a outras leis comunicacionais ${ }^{3}$.

Entre dois padrões tecnológicos e comunicacionais encarregados de suprir e ativar o debate público, deu-se a transição de uma ponta a outra. Numa ponta, temos o jornal impresso de circulação periódica (preferencialmente diária); na segunda ponta, impera a televisão de cobertura nacional, que ainda observa rotinas diárias ou semanais, mas, acima disso, dispõe do recurso da transmissão ao vivo, em que o momento do fato coincide com o momento de sua veiculação (sua representação). O modo como uma instância e outra integram o espaço público é radicalmente distinto, redundando em sociedades distintas, com vidas políticas distintas também.

Uma das marcas identitárias da cultura inaugurada pela ditadura militar no Brasil foi a consolidação do telespaço público posto pela instância da imagem ao vivo. O regime autoritário promoveu, a partir da iniciativa do Estado, a "modernização" tecnológica do sistema de mediações e midiatizações no espaço público nacional. É preciso situar no tempo histórico essa "modernização", palavra que devemos grafar entre aspas pela razão que será exposta agora. A ditadura "modernizou" a comunicação do País pelo mesmo gesto em que "desmodernizou" a política, quer dizer, a televisão no Brasil galgou avanços técnicos notáveis não apesar do atraso democrático (ou do déficit democrático), mas justamente porque se deu sob o peso desse atraso. O espetáculo mediático, nessa perspectiva, teria tido algo de mais ou menos catártico: oferecendo uma compensação à ausência de canais democráticos de participação política. Não podendo agir como cidadã, como fonte e fiscal do poder, a sociedade foi chamada a participar como plateia. 
O choque entre "modernização" e "desmodernização" delineou o perfil do telespaço público tecido autoritariamente. Este nasceu sob a tirania e pela tirania foi usurpado. A ditadura plantou nesta terra a televisão via Embratel, integrou o imaginário nacional-continental em novas bases e encontrou meios de fazer com que o telespaço público que disso resultou fosse gerido a seu favor.

Vem dessa gênese o caráter da cultura sob a ditadura militar. Não se trata de um acontecimento eventual, lateral ou decorativo, mas de um movimento estrutural, com orientação estratégica e enraizamento profundo, combinando padrão tecnológico e projeto de poder, gerando efeitos que se mostraram duradouros e persistentes. Tão duradouros e tão persistentes que, como veremos, estão atuantes e mesmo prevalentes até nossos dias, quando já se passam mais de cinquenta anos do golpe de 1964 .

Quando comparado a outros, de outras sociedades, o telespaço público à brasileira trouxe novidades em sua economia interna que ensejaram um jogo complexo de contradições singulares. A mais visível dessas novidades, que abre um prisma para várias outras, talvez seja a conjugação entre relato factual e narrativas ficcionais, compondo um dueto afinado entre telejornalismo e telenovela, inclusive no modo como ambos se articularam na grade horizontal da programação da TV, com as novelas "ensanduichando" o noticiário. Tal dueto pode ser visto como uma herança desnaturada da era do rádio (cujo apogeu se situa entre as décadas de 1930 e 1950), por meio do qual se deu a transição entre a instância da palavra impressa e a instância da imagem ao vivo. Outra novidade - que também encerra uma contradição - foi o duplo emprego (ou a dupla face) da indústria publicitária dos meios de massa: esta serviu tanto ao mercado (o capital) quanto à ditadura (o Estado); o apelo de consumo de mercadorias também operava em dueto com o apelo de patriotismo nos marcos do civismo autoritário.

Graças à dupla face da indústria publicitária, servindo simultaneamente aos dois senhores, Estado e capital mitigavam suas tensões recíprocas e encenavam um matrimônio desenvolvimentista e feliz, harmônico e profícuo. 0 
modelo econômico estatizante do regime militar exalava sua luminescência no monitor sem asperezas. O Estado ocupava todos os espaços, na exata medida em que a mercadoria ocupa todos os espaços na era do espetáculo, no dizer de Guy Debord: "O espetáculo é o momento em que a mercadoria ocupou totalmente a vida social" (1997, p. 30, grifo do autor). No imaginário arquitetado pela ditadura, a contradição entre mercadoria e governo se ocultou sob o manto cintilante do espetáculo ufanista.

Isso conferiu ao telespaço público a ambiência de um nacionalismo conservador e afetuoso, embalado por tecnologias ultramodernas que cultuavam a pátria e a mercadoria num ritual único, indivisível, redondo como bola de futebol e transparente como o vidro que recobre a tela da TV.

Tudo isso seria um tópico histórico, e de imenso interesse, não fosse o fato de que esse tópico prossegue na ordem do dia. Discutir o telespaço público na ditadura é discutir a História, por certo, mas é também, e principalmente, discutir o Brasil de hoje.

\section{A instância da palavra impressa}

A instância da palavra impressa foi fixada de modo estável entre os séculos XVIII e XIX, embora suas origens remontem, em alguns territórios nacionais, a experiências históricas anteriores. Não se deve entendê-la em termos literais, como uma folha de papel de cor de areia carimbada com letras de forma num tom entre o preto e o marrom escuro. Ela é o polo atrator do olhar social, para o qual se dirigem as atenções do público a cada ciclo de 24 horas. O papel, a tinta e a tipografia, bem como suas ferramentas de circulação e distribuição, constituem seu arcabouço técnico, mas sua matéria se situa além disso. É a pulsação em ciclos diários por meio da qual o olhar social atualiza e renova os laços que unificam o público num determinado espaço público em que vicejam os sentimentos de reconhecimento e pertencimento num todo de perfil mais ou menos nacional. Foi no seu bojo que o Estado moderno se firmou, tendo como sede física territórios recortados no mapa. 
Não subestimemos a instância da palavra impressa. Sem os jornais, os fios de entendimento que culminaram no ordenamento dos estados modernos não teriam sido viáveis. Dizendo a mesma coisa noutro nível de abstração, sem ela não teriam sido engendradas as nações como as reconhecemos hoje.

Essa instância, como é óbvio, supunha o público letrado, apto a ler e escrever nos jornais. Não havia contradição, portanto, entre esse público leitor e aquele que tomaria parte na efetivação das democracias nascentes: um público formado de homens (não por mulheres) alfabetizados, proprietários e donos de algumas (ou muitas) posses.

A informação publicada nos jornais foi vetor material - insisto no termo desse processo. A instância da palavra impressa pôs em marcha uma comunicação cujas marcas distintivas eram a interpelação racional, baseada em argumentos, e voltada para o entendimento. Para que ela vingasse como vingou, o advento da indústria gráfica, da publicidade e das linhas de distribuição de exemplares (normalmente ferroviárias) foram indispensáveis. Em muitos casos, os limites daquele espaço público eram coincidentes com os limites do alcance dos jornais que o tematizavam, sem tirar nem pôr.

Os exemplos históricos são numerosos. O mais eloquente talvez seja o caso americano. Lembremos apenas do debate nacional que resultou na adoção definitiva do federalismo como solução estável para o Estado americano. A ratificação do federalismo decorreu de intensa discussão pública (em público) que teve fórum preferencial nas páginas de jornais. A imprensa era claramente o canteiro em que se plantava a forma estatal. Naquela ocasião, John Jay, Alexander Hamilton e James Madison fizeram publicar os famosos "Federalist Papers" nos jornais The Independent Journal e The New York Packet, entre outubro de 1787 e agosto de 1788. Originalmente, os textos apareceram como anônimos ${ }^{4}$ - foi só mais tarde que seus autores se deram a conhecer. O conjunto 
dos artigos que produziram compõem um livro que logo se tornou clássico e são reputados, hoje, como pedras fundamentais do pensamento político americano.

Como demonstra o exemplo dos Estados Unidos, era na instância da palavra impressa que a sociedade civil costurava os consensos que depois seriam traduzidos nas formas de organização do estado moderno.

Caso alguém se pergunte sobre o caso brasileiro, a história é um pouco diferente. Talvez por isso mesmo, em razão das diferenças, valha a pena recapitular como as coisas se passaram por aqui. A Gazeta do Rio de Janeiro, o primeiro jornal a ser impresso em território nacional, nasceu em setembro de 1808 como órgão oficial da Coroa. Foi o Estado que o fez publicar. Não foi a sociedade. Como no Brasil o Estado engendrou a sociedade civil - e não o contrário -, a relação entre instância da palavra impressa e Estado nacional padeceu - e padece - da mesma inversão.

Como parte dessa particularidade histórica, não custa lembrar que, em nosso país, a instituição da censura nasceu antes da imprensa ${ }^{5}$. A censura se estabeleceu aqui logo após a chegada da Família Real ao Rio de Janeiro, no mesmo ano de 1808, que trouxe consigo a Imprensa Régia e as formas censórias que funcionavam em Lisboa. A Gazeta do Rio de Janeiro nasceu depois da instalação da censura portuguesa no Rio. Nasceu para referendá-la, jamais para contestá-la. É mesmo difícil classificá-la como órgão de imprensa, uma vez que, sendo porta-voz da corte, não era independente do Estado6.

A sociedade civil criada pelo Estado, que aqui chegou depois de viajar a bordo das naus portuguesas, nasceu moldada pela mentalidade patrimonialista, que se 1536, qualquer impressão de livro passava por três censuras: o Santo Ofício e Ordinário (da Igreja Católica) e o Desembargo do Paço (poder civil)" (1985, p. 29). Em 1768, o Marquês de Pombal unificou as três na Real Mesa Censória. Esta seria dissolvida em 1794, para a volta das três censuras anteriores, conforme documentou Lilia Moritz Schwarcz em A longa viagem da biblioteca dos reis: do terremoto de Lisboa à independência do Brasil (com Paulo Cesar de Azevedo e Angela Marques da Costa), publicado em 2002 pela Companhia das Letras. A despeito de mudanças de forma, a vigilância das leis da Coroa permaneceu inabalável, tanto que viajou junto com a corte - e sua tipografia - de Lisboa para o Rio de Janeiro. 
apoiava na concentração de poder. A comunicação resultante daí não era, portanto, democrática - muito menos democratizante. Era, de nascença, uma comunicação a serviço da autoridade. Desse modo, o espaço público gerado pela instância da palavra impressa no Brasil teve uma conformação autoritária desde sua gênese um traço que, guardadas as proporções, seria reproduzido pela criação do telespaço público pela instância da imagem ao vivo, por força da iniciativa da ditadura militar.

Mas fiquemos ainda um pouco no passado mais longínquo. Há um detalhe, ainda no começo do século XIX, bastante, digamos, instrutivo. Esse detalhe se chamava Correio Braziliense. Trata-se do primeiro veículo jornalístico de fato independente da história brasileira, um mensário que tinha formato de livro. 0 Correio Brasiliense foi lançado três meses antes do lançamento da Gazeta, mas igualmente depois da censura. Sua sede ficava no exílio. Fundado em junho de 1808 por Hipólito José da Costa, que fugira da cadeia em Portugal, onde era perseguido político, o Correio era redigido e impresso em língua portuguesa, mas em Londres, e sua circulação no Brasil foi prontamente proibida, logo no nascedouro. A censura contra ele se manteve até 1822, quando o jornal parou de circular. Durante todo esse tempo, foi lido e exerceu influência na terra brasileira, mas clandestinamente. É interessante, além de muito esclarecedor, lembrar que a circulação clandestina do Correio se tornaria uma instituição informal da nação. Dom João VI, por vias pouco oficiais, apoiou com uma das mãos o projeto editorial de Hipólito José da Costa (GOMES, 2007). Com a outra mão, bruta, manteve o veto o tempo todo7.

\section{A instância da imagem ao vivo}

Anotadas as contradições e as ambivalências do limiar do espaço público nacional brasileiro, saltemos agora para a instância da imagem ao vivo e para o seu modo específico de integrar as sociedades. 
Antes de tudo, um esclarecimento preliminar. Por "instância da imagem ao vivo" não se deve entender exclusivamente as transmissões ao vivo. A instância não se reduz ao ato: ela compreende a condição imediata e permanente de estar ao vivo a qualquer instante. A instância da imagem ao vivo não é a imagem ao vivo, em si, mas o lugar social que lhe serve de sede, a partir do qual ela se irradia e para o qual ela converge, em retorno. Também por isso, o que se chama correntemente de "on-line", esse atributo peculiar das redes interconectadas da era digital, é parte dessa instância, posto que a prolonga. Para que a ideia de instância de imagem ao vivo possa ganhar definições mais nítidas, seria prudente uma escala em Walter Benjamin, numa passagem em que ele detecta uma paixão das "massas modernas":

Fazer as coisas "ficarem mais próximas" é uma preocupação tão apaixonada das massas modernas como sua tendência a superar o caráter único de todos os fatos através da sua reprodutibilidade técnica. Cada dia fica mais irresistível a necessidade de possuir o objeto, de tão perto quanto possível, na imagem, ou antes, na sua cópia, na sua reprodução (1994, p. 170-171).

O curso desimpedido da imagem pelos meios de comunicação produziu transformações irreversíveis. Com o surgimento da televisão, deu-se uma expansão que mudaria tudo. As retrancas até então contidas, quase tímidas, que, na paginação dos diários, abrigavam os espaços destinados ao divertimento do leitorado, como os folhetins, os desenhos humorísticos e eventualmente os aconselhamentos sobre assuntos da vida privada (do horóscopo às receitas culinárias, passando pelos "consultórios sentimentais"), ganharam proeminência. O que era acessório - a diversão - se converteu em carro-chefe da comunicação. As notícias pretensamente sérias, os artigos de fundo, esses é que se tornaram caudatários. Quem passou para o primeiro vagão foi o entretenimento, tanto nos meios impressos (com a explosão das revistas de variedades) como nas emissoras e nas redes de televisão, que emulavam e radicalizavam as fórmulas ensaiadas pelo rádio. 
A densidade e a natureza do público também mudariam para sempre. O público não mais se restringia aos alfabetizados. As "massas modernas", como define Benjamin, incluíam as massas iletradas, novas ingressantes no espaço público ampliado, marcadamente acrítico, que logo se transformaria em telespaço público. Os conteúdos também se alteram - inteiramente. O argumento racional, típico dos jornais clássicos, perde terreno para o apelo de sedução sensorial, o que é rapidamente impulsionado pela indústria da publicidade e pela generalização da indústria do entretenimento, umbilicalmente associada à primeira. O campo do sensível ganha novos domínios. O imaginário avança sobre o simbólico. O espaço público (expressão que uso aqui como sinônimo da esfera pública) se torna um espaço estético, além de ético.

Nesse ponto, vale ter em mente uma das definições que Jürgen Habermas dá à esfera pública. Diz ele que a esfera pública "não se refere nem às funções nem ao conteúdo da comunicação de todo dia mas ao espaço social gerado pela comunicação" (1996, p. 360). Essa noção faz toda a diferença. A esfera pública não é estatal, não cabe nas formas institucionais, não é legal, não é jurídica - e também não é sociológica. Ela é, sim, o espaço social gerado pela comunicação. A partir disso, ficam menos obscuras as razões pelas quais a comunicação posta por lógicas autoritárias produz espaços públicos de moldes autoritários. Fica mais claro, também, por que a comunicação que interpela, não a razão, mas o desejo do sujeito, gera espaços públicos fortemente definidos pelo fetiche - da mercadoria, de um lado, e do carisma de políticos, de outro.

Outra característica da comunicação posta pela instância da imagem ao vivo está no transbordamento das fronteiras nacionais. Enquanto a instância da palavra impressa se situa do lado de dentro do perímetro do alcance dos veículos impressos - alcance que depende da distribuição física e, acima disso, depende do letramento naquele idioma específico, o que a circunscreve dentro de contornos mais ou menos nacionais - , a instância da imagem ao vivo, conduzida pela imagem eletrônica e pelas linguagens do entretenimento, que suplantam a linguagem estrita do jornalismo em seu sentido político, interpela o desejo - 
não a consciência racional - do sujeito e ultrapassa as fronteiras idiomáticas, geográficas e nacionais.

Aquele espaço público, de pretensões racionais, voltado para o entendimento (ou para o acordo imposto pela força, mas com formatos contratuais que simulavam um entendimento), baseado na tematização do interesse comum e dos assuntos públicos, explode em uma arena de outra natureza, o telespaço público. Este tende a abarcar sociedades de línguas distintas - e de países distintos. A expansão é de tal magnitude que Octavio Ianni enxergou nela a tessitura de uma "sociedade civil global":

\begin{abstract}
As sociedades contemporâneas, a despeito das suas diversidades e tensões internas e externas, estão articuladas numa sociedade global. [...] O que começa a predominar, a apresentar-se como uma determinação básica, constitutiva, é a sociedade global, a totalidade na qual pouco a pouco tudo o mais começa a parecer parte, segmento, elo, momento. São singularidades, ou particularidades, cuja fisionomia possui ao menos um traço fundamental conferido pelo todo, pelos movimentos da sociedade civil global $(1998, \text { p. } 39)^{8}$.
\end{abstract}

Procedamos então a uma síntese. Os estados nacionais floresceram no canteiro do espaço público forjado pela instância da palavra impressa, da qual incorporaram ritos e linguagens em todos os níveis (basta ver a centralidade dos "diários oficiais", de periodicidade diária, no linguajar da administração pública). O telespaço público, que requer a existência daquele espaço público como premissa, projeta a emergência de uma "sociedade civil global", ou seja, o telespaço público nacional volta o espaço nacional para fora, em muitas vias.

Não é custoso observar que isso nos coloca um problema para a análise do caso brasileiro. O telespaço público é por definição compatível com a lógica da economia e da cultura globalizadas. No entanto, sua constituição no Brasil, por obra da ditadura militar, dava sequência a uma estratégia explicitamente nacionalista, nos piores sentidos da palavra. Como uma coisa se conciliou com a outra? 
A resposta é: de modo precário e instável. Por acidente ou por premeditação inconfessa, o fato é que o telespaço público no Brasil abriu os canais necessários para a indústria global do audiovisual, numa escala muito superior àquela que fora estabelecida pelo mercado cinematográfico nas décadas precedentes. Nessa perspectiva, o ordenamento da cultura brasileira nos marcos do regime militar, de viés propagandisticamente nacionalista, quase xenófobo, era também internacionalizante - numa dimensão que talvez não fizesse parte dos planos culturais dos militares no poder. Para os contornos do telespaço público, o idioma não é mais requisito - ele se expande quase que inercialmente, fundindo-se a outros. Mais do que isso, os meios físicos e, notadamente, a presença física, são quase irrelevantes.

\section{O telespaço público}

Isso posto, vejamos alguns aspectos complementares do conceito de telespaço público. Liberto da necessidade das presenças físicas, o telespaço público admite, segundo Paul Virilio, as "telepresenças" (1996). Virilio distingue três lógicas na história da imagem: a lógica formal (aquela que presidiu a pintura, gravura, arquitetura), que teria terminado no século XVIII; a dialética (do fotograma, na fotografia ou no cinema), própria da mentalidade do século XIX; e a lógica paradoxal, que começa com a invenção da videografia, da holografia e da infografia. De acordo com esse modelo, estaríamos na era da lógica paradoxal, que não depende da presença física, podendo ser ativada pela "telepresença".

O paradoxo lógico está no fato de essa imagem em tempo real dominar a coisa representada, nesse tempo que torna-se mais importante hoje do que o espaço real. Essa virtualidade que domina a atualidade, perturbando a própria noção de "realidade". Daí essa crise das representações públicas tradicionais (gráficas, fotográfica, cinematográficas...) em benefício de uma apresentação, de uma presença paradoxal, telepresença à distância do objeto ou do ser que suplanta sua própria existência, aqui e agora (Ibid., p. 131). 
A telepresença é vista por Virilio como condição do objeto - mas devemos entendê-la igualmente como condição do sujeito. Devo acrescentar que foi esse termo, "telepresença", lavrado pelo autor, que me motivou a pensar no conceito de telespaço público. Um espaço constituído por telepresenças há de ser um telespaço, já que não depende da presença física de objetos e sujeitos, da circulação física de órgãos de imprensa e de espaços urbanos físicos para a existência do espaço público ampliado, capaz de gerar efeitos políticos, econômicos ou culturais.

Não sendo mais o espaço público da outra era, mas o espaço público historicamente gerado pela instância da imagem ao vivo (que se complexificou, mas não se revogou, com as tecnologias digitais), o espaço público assume as características do telespaço público, a partir de cinco deslocamentos históricos que afetam suas condições de tempo e espaço":

1. O primeiro deslocamento se refere à sua materialidade. O telespaço público tem sua materialidade não mais nos lugares físicos - espaços urbanos, espaços arquitetônicos, espaços projetados e construídos nem mesmo nos espaços sociais, mesmo que concebidos em termos não físicos (por exemplo, o espaço social do grupo linguístico, ou o espaço nacional conformado pelo eleitorado de um país). Agora, a materialidade é dada pelas teias da comunicação industrial que o enseja. Para encontros, dissidências ou entendimentos, atuam as telepresenças de que fala Paul Virilio. Elas estão no signo da imagem eletrônica, ou, em poucas palavras, nos espaços demarcados agora, em lugar da geografia, pela instância da imagem ao vivo. A virtualidade, aqui, não é a negação do que é material, mas a expansão eletrônica (material, portanto) dos espaços sociais. 
2. O segundo deslocamento é a supressão do ideal do entendimento e da utopia do consenso - tão caros ao espaço público gerado pela instância da palavra impressa - em favor do discurso que não precisa suprimir o conflito, de um lado, e das identificações, de outro, que não são mediadas pela razão, pelo consciente. O conflito não é sinônimo de enfrentamento armado; apenas indica que o telespaço público não se rompe caso não se ampare sobre o consenso. $E$, interessante observar, mesmo a emergência de guerras não o suprimem. Antes, as guerras opunham dois espaços públicos (nacionais). No telespaço público, as guerras têm lugar dentro dele. O desentendimento, enfim, não Ihe prefigura um problema.

3. O terceiro deslocamento se refere ao declínio dos significados em face da hipertrofia dos significantes. A forma de significar prevalece. A hegemonia não é mais exercida por uma ideia, por um "conteúdo", mas pelo sistema de significantes inaugurado pela instância da imagem ao vivo, pela imagem eletrônica.

4. O quarto é a falência do sujeito dito racional e a emergência (a admissão, em tese) do sujeito do inconsciente como agente do (e no) telespaço público. As relações dialógicas são abertamente assimétricas. O cidadão se transubstancia em consumidor de "direitos". O desejo precede a vontade.

5. Por fim, o quinto deslocamento: enquanto o espaço público tende ao centro, o telespaço público escapa. É centrífugo. Não corre para dentro, mas para fora. Não se define por ser uno, mas por ser fragmentável e fragmentado. Subdivide-se em incontáveis espaços públicos plurais, que vão da esfera íntima à esfera global. Fragmentase sem perder a referência em si mesmo. O seu todo é a convivência de suas fragmentações.

Voltemos agora ao modo como a ditadura inaugurou o telespaço público no Brasil. 


\section{Arbítrio e comunicação}

Como já foi apontado, há uma contradição de fundo entre o ideário nacionalista e centralizador da ditadura militar e o telespaço público fabricado sob seus auspícios. Sendo telespaço público, tinha propensão intrínseca ao fragmentário, ao transbordamento das fronteiras nacionais e à compatibilidade sistêmica com o mercado global - que é progressivamente o mercado das imagens. Sendo telespaço público, trazia em seu âmago o impulso centrífugo em relação ao aparelho de Estado e convergente em relação ao capital. Mesmo assim, a despeito daquilo que nele tenderia ao fragmentário, centrífugo, internacionalizante e capitalista, ele cumpriu seu ciclo sob o autoritarismo militar que o patrocinou. Depois disso, com o ocaso da ditadura, seguiu sua vocação. $O$ interessante, mas não surpreendente, é que ele manteve, mesmo após a ditadura, a vigência dos ícones patrióticos na forma de âncoras imaginárias recorrentes.

Ainda quanto a essa contradição, registremos que os estrategistas militares tinham a meta de usar a comunicação para cimentar o culto da potência nacional. Seu nacionalismo desaguava em um ideal de força bélica. O telespaço público pode servir a tais propósitos, por certo, mas não sem ruídos graves, que estiveram presentes no projeto autoritário brasileiro. Não há de ser impróprio considerar que as fantasias dos ideólogos do regime abrigassem o sonho de lograr, com a máquina de propaganda oficial via Embratel, um efeito estético agregador análogo àquele que tinha sido transitoriamente alcançado pelas máquinas de propaganda de estados totalitários anteriores, como o do nazismo alemão no período imediatamente anterior à Segunda Guerra. Ainda que, nas pretensões dos ditadores daqui, o projeto não fosse totalitário, o recurso ao didatismo doutrinário e as tentativas de conferir carisma aos líderes do regime como portadores da força e da consciência nacional sugerem que viam no totalitarismo uma inspiração, mesmo que longínqua.

As relações de produção da nova indústria cultural mobilizadas para isso, contudo, não replicavam as do totalitarismo, concebidas e diretamente operadas pela mão estatal. O modo de produção do repertório audiovisual deflagrado com 
o golpe militar de 1964 tinha um pilar indispensável alicerçado no mercado, o que mudava tudo. Em suas fantasias, a ditadura talvez imaginasse poder cooptar o mercado (o capital), mas isso, claro, não passava de fantasia, incapaz de neutralizar as contradições que estruturavam o modelo adotado.

O pilar no mercado e o pilar estatal encontraram sua simbiose azeitada, mas a convivência era mais tática que estratégica, para falar na língua dos ideólogos militares. Com o fim do regime militar, seu aparato de propaganda seguiu adiante, sem a companhia das fardas, cada vez mais na órbita do capital, não necessariamente brasileiro. A contradição foi vencida pelo cansaço e pelo esgotamento (da ditadura) e pela natureza do telespaço público; não foi obra de um suposto engenho dos golpistas ou de um ocasional brilhantismo empreendedor dos gerentes privados do negócio. No outono da tirania armada, restaram seus frutos tecnológicos que adquiriram vida própria na democracia que engatinhava e no mercado que se internacionalizava.

No plano da imagem, da representação e das narrativas, o dueto entre ficção e jornalismo, que alcançou o apogeu nos tempos mais violentos da repressão política e mais exuberantes da economia, refletiu a mesma contradição de fundo. É realmente incrível como, nos anos 1970, enquanto o telejornalismo divulgava uma narrativa rigorosamente ficcional, poucas pílulas de real eram admitidas na televisão pela porta das obras ficcionais. Enquanto os locutores dos noticiários, acuados pela censura oficial, mas não apenas por isso, falavam em barítono uníssono sobre os grandes progressos do "país que vai pra frente", as arestas da realidade social, ainda que em relatos abrandados, entravam nos diálogos da telenovela.

A admissão das pílulas de real não se devia a um capricho de um ou outro; constituía um recurso inescapável para precipitar a aderência dos olhos ariscos do público ao monitor da TV. Não foi nada intencional ou planejado, mas, nesse aspecto, a criatividade um tanto anárquica de roteiristas e artistas acharam um caminho dramatúrgico que se mostrou eficaz. No Brasil, a telenovela se diferenciou de suas matrizes - entre elas o dramalhão mexicano e as radionovelas de enredo quase circense - exatamente porque soube incorporar ao seu formato 
melodramático bastante convencional um repertório realista. Não há de ter sido mera coincidência a presença marcante de escritores de esquerda na criação de telenovelas de grande sucesso.

Se a indústria da ficção trouxe para dentro da TV os dissidentes políticos, contestadores da ditadura, não há de ter sido por altruísmo ou por opção política, mas por necessidade. Sem esse talento inquieto, teria sido muito mais difícil atrair o olhar e o desejo inconsciente das massas urbanas que cresciam e se multiplicavam. Foi a necessidade de amalgamar o todo imaginário, de compor o universo (uno e indivisível) do congraçamento patriótico tão ao gosto da ditadura, que impeliu a indústria a investir em roteiros carregados de elementos da realidade - o que teve início de modo memorável com a novela Beto Rockfeller, de Bráulio Pedroso, exibida entre 1968 e 1969 pela TV Tupi (suas cenas externas, rodadas na rua, alterariam sensivelmente os padrões estéticos das telenovelas). Tratava-se de um imperativo estrutural do telespaço público: em oposição às suas próprias forças centrífugas, ele dependia, como ainda depende, de ter fatores de coesão de público, que propiciam o sentido de unidade imaginária. Ao lado da simbologia patriótica, que incluiu o futebol, as telenovelas e os telejornais cumpriram essa função.

Em suma, a ficção da TV a serviço do regime militar contou paradoxalmente, sim, posto que a lógica é paradoxal, mas não ilógica - com o talento de autores de oposição. Entre eles, havia comunistas declarados ou, pelo menos, direta ou indiretamente ligados às organizações clandestinas de esquerda, como Oduvaldo Vianna Filho, Dias Gomes, Gianfrancesco Guarnieri, Lauro César Muniz e Walter George Durst. Romancistas festejados pelo Kremlin, como Jorge Amado, teriam suas obras convertidas em sucessos marcantes da TV. Numa genial adaptação de Walter George Durst, a novela Gabriela, da obra homônima do escritor baiano, representou uma revolução estética na tela da Rede Globo, aclamada pela audiência e também pela crítica. Isso tudo em 1975, o mesmo ano em que o jornalista Vladimir Herzog foi assassinado numa cela do DOI-CODI, no Quartel-General do II Exército, em São Paulo. 
Antes de Gabriela, no mesmo horário das dez da noite, foi ao ar O Rebu, uma trama em 112 capítulos escrita por Bráulio Pedroso, tendo como protagonista o ator e diretor Zbigniew Ziembinski no papel de um personagem cuja homossexualidade, ainda que contida (eram tempos de censores ferozes), era muito clara. Nas telenovelas, a problematização dos costumes e das moralidades dominantes foi se tornando uma constante. As frequentes investidas da tesoura federal contra os autores não davam conta de refreá-la. O êxito da TV como engrenagem de legitimação do ideário da ditadura dependia desse tipo de concessão. Era uma rendição relativa do Estado ao mercado; o preço que a ditadura aceitava pagar para que sua propaganda conseguisse unificar o imaginário nacional, com atrações capazes de seduzir os olhos das massas. O realismo da narrativa de ficção, ao lado do irrealismo tão falso quanto edificante dos telejornais, mantinha um dueto que se contrapunha à força centrífuga inata do telespaço público.

O preço era alto, implicava riscos óbvios, mas valeu (para a ditadura). A concessão deu resultados. Além disso, não havia outro caminho para a camarilha que tinha o poder mas não tinha o controle estrito das relações de produção do entretenimento. Enquanto isso, impingia seus bordões de propaganda oficial nos meios tecnologicamente avançados, com mensagens ultraconservadoras e imagens de gozo auriverde.

É necessário - ainda que tormentoso - que recordemos algumas dessas campanhas "cívicas". Um dos dísticos mais marcantes foi o "Brasil, ame-o ou deixe-o". A frase, de pronúncia fonoaudiologicamente impraticável, sobrecarregada de hiatos mal acomodados, era uma tradução infame de um slogan a favor da Guerra do Vietnã, veiculado pelo governo americano, que, em inglês, era muito mais sonoro: "America: love it or leave it". O abrasileiramento da pregação do Tio Sam era de mau gosto em todos os sentidos.

Outro bordão nacional, que já foi citado aqui, embalou o clima do Brasil tricampeão de futebol: "Este é um país que vai pra frente". Eram "90 milhões em ação", felizes, enquanto a tortura, dentro das repartições públicas, dizimava cidadãos que discordavam. 


\section{A atualidade do imaginário forjado na repressão}

Daqueles tempos, ficou para nós uma herança, ou maldição, que é a forma de ordenamento da cultura. A ditadura se foi, mas muito do caráter do telespaço público que ela nos legou permanece. Ele se revelou resiliente e, em alguns de seus aspectos constitutivos, quase inamovível. Após o fim do regime de exceção, sucedido por uma democracia desprovida da necessária institucionalidade, que custaria décadas para amadurecer e se regularizar, o telespaço público gerado pela instância da imagem ao vivo sob o jugo ditatorial ainda está aí. Nossa democracia, hoje mais sólida, passa por ele. O debate público passa por ele.

Hoje, as campanhas eleitorais se resolvem no âmbito do horário eleitoral na TV. Um minuto dentro desse horário alcança enorme valor no mercado político - e no mercado das doações de campanha. A representação da política no telespaço público ainda se define nos marcos da TV, que exporta seus padrões imagéticos para as redes sociais, onde repercute fortemente. A identidade nacional ainda se traduz em termos televisivos, hoje instalados em outros suportes e em outras plataformas (marcadamente nas redes sociais e na internet) e não se restringem unicamente à televisão aberta. 0 telespaço público se complexificou acentuadamente, sem dúvida, mas, em seus parâmetros centrais, permanece.

O imaginário de patriotismo, um dos traços mais perceptíveis dessa manutenção, praticamente não se alterou, e, quanto a isso, temos fartas provas materiais, colhidas diretamente das campanhas publicitárias dos governos que se sucederam, até hoje. Chega a ser constrangedora a proximidade - ou mesmo a identidade - entre os bordões da ditadura e aqueles mobilizados durante o primeiro governo de Luiz Inácio Lula da Silva, entre 2003 e 2006.

Onde a ditadura entoava "Este é um país que vai pra frente", o governo Lula repetia "Sou brasileiro e não desisto nunca". As duas proposições se equivalem em sua vacuidade. Poderiam ser permutadas entre os dois períodos sem que nenhum efeito perturbador acontecesse em um ou em outro. São duas proposições irmãs, para começar, em sua irracionalidade, o que é muito simples 
constatar. Se o Brasil "é um país que vai pra frente", devemos supor que os outros países vão "pra trás"? Se não vão, em que o Brasil se diferencia dos demais? O mesmo efeito acontece com "sou brasileiro e não desisto nunca", campanha festiva do primeiro mandato de Lula. Os uruguaios por acaso desistem de primeira? Os guatemaltecos desistem sempre? Os chineses desistem na terceira tentativa? Por que a afirmação gratuita de que "não desiste nunca" deveria elevar a autoestima - expressão muito em voga no governo Lula - do brasileiro?

Os dois bordões, o dos militares e o de Lula, são inertes. Ecoam um patriotismo sem fundamento, na vã tentativa de forçar um fanatismo segundo o qual o Brasil seria superior aos outros países simplesmente porque é o Brasil. Impressiona que os significantes propagandísticos da ditadura não tenham se renovado na experiência democrática, ainda que saibamos que, se eles não se renovaram, isso não se deve à persistência do espírito da ditadura, mas à persistência da matriz do telespaço público que ela mandou fabricar.

Caso o primeiro exemplo não tenha sido suficiente, pense-se em outro dístico bastante trabalhado durante o primeiro governo Lula: "O melhor do Brasil é o brasileiro". A frase, extraída da obra de Câmara Cascudo ("O melhor produto do Brasil ainda é o brasileiro"), dentro da qual tinha pertinência - explicitar que o Brasil não é um lugar geográfico, mas um povo -, foi deslocada de seu contexto original e transplantada para a propaganda de Estado no século XXI, gerando uma platitude sem contexto nem racionalidade. Por acaso o melhor do Brasil poderia ser o irlandês? Ou o paraguaio? Ou o melhor da Coreia do Norte poderia ser o brasileiro? O que há nesse slogan publicitário para acender o orgulho nacional? Outra vez, a frase poderia ter sido usada na ditadura militar e não faria a menor diferença: para pior ou para melhor.

No telespaço público brasileiro, a organização da cultura promovida pela ditadura pouco se alterou. Mesmo as forças que se declaram democráticas tentam reeditar os feitiços que supostamente davam certo durante o período de exceção. Existe aí algo de treva e é com ela que temos contato direto quando o poder ambiciona a perpetuação de si mesmo. 


\section{Referências}

BENJAMIN, W. A obra de arte na era de sua reprodutibilidade técnica (Primeira versão). In: . Obras escolhidas: Magia e técnica, arte e política - ensaios sobre literatura e história da cultura. São Paulo: Brasiliense, 1994. p. 165-196. Volume 1.

BUCCI, E. Televisão objeto: a crítica e suas questões de método. 2002. 299 f. Tese (Doutorado em Comunicação) - Escola de Comunicações e Artes da Universidade de São Paulo, São Paulo, 2002.

BUCCI, E. Em torno da instância da imagem ao vivo. Matrizes, São Paulo, v. 3, n. 1, p. 65-79, 2009. Disponível em: <http://www.revistas.usp.br/matrizes/ article/view/38241/41024>. Acesso em: 18 jan. 2017.

DEBORD, G. A sociedade do espetáculo: comentários sobre a sociedade do espetáculo. Rio de Janeiro: Contraponto, 1997.

DINES, A. (Org. ). 200 anos do Correio Braziliense. São Paulo: Imprensa Oficial, 2008.

GOMES, L. 1808: como uma rainha louca, um príncipe medroso e uma corte corrupta enganaram Napoleão e mudaram a história de Portugal e do Brasil. São Paulo: Planeta do Brasil, 2007.

HABERMAS, J. Between facts and norms: contributions to a discourse theory of law and democracy. Cambridge, MA: MIT, 1996.

IANNI, O. A sociedade global. Rio de Janeiro: Civilização Brasileira, 1998.

MILANESI, L. O que é biblioteca. São Paulo: Brasiliense, 1985. 
SCHWARCZ, L. M.; COSTA, A. M.; AZEVEDO, P. C. A longa viagem da biblioteca dos reis: do terremoto de Lisboa à independência do Brasil. São Paulo: Companhia das Letras, 2002.

VIRILIO, P. A imagem virtual mental e instrumental. In: PARENTE, A. (Org.). Imagem máquina: a era das tecnologias do virtual. Rio de Janeiro: Editora 34, 1996. p. $127-132$.

submetido em: 15 jul. 2016 | aprovado em: 15 ago. 2016 